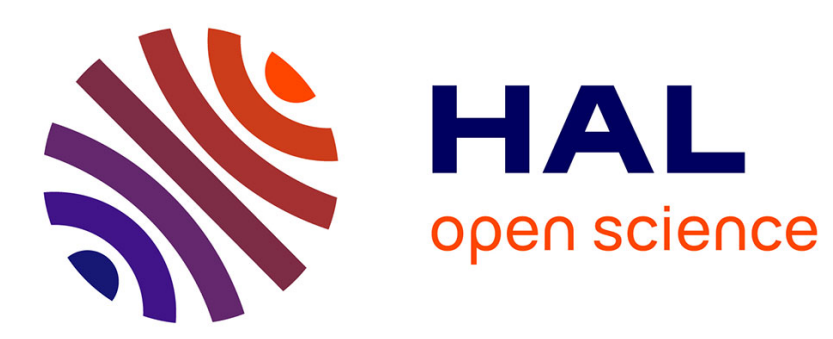

\title{
Managing watershed services of tropical forests and plantations: Can meta-analyses help?
}

Bruno Locatelli, Raffaele Vignola

\section{To cite this version:}

Bruno Locatelli, Raffaele Vignola. Managing watershed services of tropical forests and plantations: Can meta-analyses help?. Forest Ecology and Management, 2009, 258 (9), pp.1864-1870. 10.1016/j.foreco.2009.01.015 . cirad-00699344

\section{HAL Id: cirad-00699344 http://hal.cirad.fr/cirad-00699344}

Submitted on 20 May 2012

HAL is a multi-disciplinary open access archive for the deposit and dissemination of scientific research documents, whether they are published or not. The documents may come from teaching and research institutions in France or abroad, or from public or private research centers.
L'archive ouverte pluridisciplinaire HAL, est destinée au dépôt et à la diffusion de documents scientifiques de niveau recherche, publiés ou non, émanant des établissements d'enseignement et de recherche français ou étrangers, des laboratoires publics ou privés. 


\title{
Managing watershed services of tropical forests and plantations: can meta-analyses help?
}

Bruno Locatelli (a*), Raffaele Vignola (b),

(a) CIRAD UPR Forest Resources, Montpellier 34398, France; CIFOR ENV Programme, PO Box 0113 BOCBD, Bogor 16000, Indonesia

(b) CATIE Global Change Group, Turrialba 7170, Costa Rica

(*) Corresponding author. Tel.: +62.251.622.622; fax: +62.251.622.100. Email address: bruno.locatelli@cirad.fr

Accepted version of: Locatelli B., Vignola R., 2009. Managing watershed services of tropical forests and plantations: Can meta-analyses help? Forest Ecology and Management 258(9): 1864-1870. doi:10.1016/j.foreco.2009.01.015

\begin{abstract}
The watershed services provided by tropical natural and planted forests are critical to human well-being. An increasing number of valuation studies and experiences with payment for ecosystem services have dealt with the role of ecosystems in regulating the flow of water. However, several studies have been based on misconceptions about the role of forests and plantations in the hydrological cycle, despite the publication of many reviews by hydrologists. The objective of this paper is to evaluate whether meta-analyses applied to studies comparing water flows in tropical watersheds under natural or planted forests and non-forest lands can provide useful results for valuing watershed ecosystem services and making decisions. The metaanalyses show significantly lower total flows or base flows under planted forests than non-forest land uses. Meta-analyses conducted with subsamples of the data also show lower total flow and higher base flow under natural forests than non-forest land uses. However, the available studies were restricted to humid climates and particular forest types (Pinus and Eucalyptus planted forests and lowland natural forests). The small number of available studies with sufficient original data is a major constraint in the application of metaanalyses. This represents a major technical challenge for valuation studies or payment for ecosystem services, especially in countries where financial resources for implementing field research are scarce.
\end{abstract}

\section{Keywords}

ecosystem services; tropics; natural forest; planted forests; hydrology; policy; meta-analysis 


\section{Introduction}

Ecosystems provide services critical to human well-being, in particular watershed services that regulate the quantity of water available for human activities. The conservation of dry season stream flows is essential for navigation, recreation, wildlife, and for rural communities, as well as for irrigation systems that lack the technology for pumping groundwater (Aylward, 2005). The reduction of storm flow may benefit housing, infrastructure, or agriculture in flood-prone areas. The conservation of total annual water flow is also relevant to reservoirs for drinking water or hydroelectricity production (Guo et al., 2000).

Over the past 50 years, however, the conversion of natural ecosystems to other land uses has dramatically altered hydrological cycles (Millennium Ecosystem Assessment, 2005). The combined effects of climate and land cover changes require societies to adopt appropriate adaptation measures for reducing their vulnerability to water scarcity and excess (Oki et al., 2006; Hulme, 2005). These measures should include the protection or restoration of ecosystems providing watershed services, especially in developing countries with low technical and financial capacity to regulate water flows with engineered solutions (Bergkamp et al., 2003; Pattanayak, 2004). In this respect, financial mechanisms that encourage the provision of ecosystem services, such as payments for ecosystem services (PES), are increasingly being used to manage upstream forest ecosystems for the regulation of water flows (Wunder, 2005; FAO, 2004; Dudley et al., 2003).

Valuation studies of watershed ecosystem services and management or policy decisions about PES are not always scientifically sound. Various misconceptions about the role of ecosystems in regulating the flow of water persist among managers and decision-makers, despite the publication of many scientific papers on this issue (e.g., Bosch and Hewlett, 1982; Bruijnzeel, 1990; Critchley and Bruijnzeel, 1996; Sahin and Hall, 1996; Bonell, 1998; Calder, 2002; Best et al., 2003; Andreassian, 2004; Bruijnzeel, 2004; Scott et al., 2004; Bonell and Bruijnzeel, 2005; Farley et al., 2005; Guillemette et al., 2005; Scott et al., 2005). A challenge facing managers and decision-makers is the complexity of the effect of ecosystems on water flows (Bruijnzeel, 1990; Fujieda et al. 1997; Bonell, 1998; van Noordwijk et al., 2004; Waage et al., 2008).).

Meta-analysis, a statistical technique for combining the quantitative findings of several studies, has seldom been used in forest hydrology (Ilstedt et al., 2007). Meta-analysis has the ability to consider several studies that are in themselves inconclusive, and provide a statistically conclusive synthesis. Although it requires simplification of the observed phenomena, meta-analysis has the advantage of producing results that are more easily understandable by decision-makers than narrative reviews. The objective of this paper is to evaluate whether meta-analyses applied to studies comparing water flows in tropical watersheds under different forest or non-forest covers can provide useful results for valuing watershed ecosystem services and making decisions about PES and watershed management.

\section{Method}

We conducted several meta-analyses to combine the findings of studies comparing water flows between watersheds under natural forests vs. non-forest land uses, and planted forests vs. non-forest land uses. These studies were synchronic comparisons of two or more paired watersheds or diachronic comparisons of one watershed under changing forest cover over time. We considered natural and planted forests because both are being considered in PES for watersheds (Wunder et al., 2008). For instance, the national PES scheme in Costa Rica rewards forest conservation and plantation and recognizes explicitly hydrological services, including the provision of water for human consumption, irrigation, and energy production (Pagiola, 2008).

We considered three hydrological variables of interest: annual total flow, storm flow, and base flow. According to the Glossary of Hydrology of UNESCO-WMO (1992), annual total flow is the "total volume of water that flows during a year, usually referring to the outflow of a drainage area or river basin". Storm flow is "part of surface runoff which reaches the catchment outlet shortly after the rain starts; its volume is equal to rainfall excess". Base flow is the "part of the discharge (volume of water flowing through a river or 
channel cross-section in unit time) which enters a stream channel from groundwater from lakes and glaciers during long periods when no precipitation or snowmelt occurs” (UNESCO-WMO, 1992). Other authors have modified this definition by adding that base flow is "the more or less permanent flow supplied to drainage channels by rather invariable sources" (Susswein et al., 2001). In areas with seasonality in rainfall, the discharge during most of the dry season results from base flow (Smakhtin, 2001).

We followed the generally accepted procedures for meta-analysis (e.g., Cooper and Hedges, 1994; Gurevitch et al., 2001). First, we searched peer-reviewed articles comparing water flows under natural or planted forests and non-forest land uses in tropical watersheds. We searched references in CAB, ISI Web of Science, and the AGRICOLA literature database in March 2006 with the following query: "(forest OR deforestation OR reforestation OR afforestation) AND (water OR hydrology OR hydrological) AND (watershed OR catchment OR land use OR land-use) AND (tropical OR subtropical)”. About 1100 references were retrieved.

Second, we selected studies conducted in whole watersheds (i.e., not in plots) that compared several watersheds under different land-uses during several years or one catchment during several years before and after a land-use change. We selected only studies reporting field measurements (i.e., not modeling results) and providing "sufficient data". By "sufficient data", we mean that the studies reported one of the following data combinations: (1) annual values of a hydrological variable for each watershed and each year, or (2) means and standard deviations of a hydrological variable and the number of observations for watersheds under forests and non-forest land uses. This selection resulted in only 10 studies. To ensure a larger sample, we searched for documents cited by review articles that complied with our selection criteria, and retrieved 10 more studies. We characterized the studies according to forest type (planted vs. natural forests), watershed area, humidity index, and forest cover difference. Data about the humidity index, defined as the ratio of annual precipitation and potential evapotranspiration, came from Deichmann and Eklundh (1991). Forest cover difference was defined as the difference in forest cover between the compared watersheds, and was considered to be high if it was more than $50 \%$ of the watershed area.

Third, each comparison (i.e. comparison of one hydrological variable between different watersheds) found in the selected studies was converted to a dimensionless scale called the effect size. We chose the Hedge's unbiased estimator g of effect size, and used equations described by Cooper and Hedges (1994) to estimate the effect size and its variance for each comparison. Fourth, we combined the estimates of effect sizes using a random effect model that considers a random variation among the studies in the "true" effect (Gurevitch et al., 2001; Shadish and Hoaddock, 1994). We conducted six meta-analyses for each of the three hydrological variables of interest and for natural and planted forests. We also applied meta-analyses to subsets of the data, e.g., only small watersheds. Finally, for each meta-analysis, we conducted a sensitivity analysis to determine whether some individual comparisons influenced the results, by performing $n$ partial meta-analyses ( $n$ being the number of comparisons) on data sub-samples containing all the comparisons but the $\mathrm{n}^{\text {th }}$ one. Only significant differences (at $\mathrm{p}<0.05$ ) observed in a meta-analysis and all associated partial meta-analyses were reported. We considered that the tendency to report only significant results - or the "file drawer problem" (Fernandez-Duque and Valeggia, 1994) - was not a relevant bias in our analysis, because the results of costly long-term hydrological studies are generally reported even if no significant differences are found.

\section{Results and discussion}

\section{Selected studies}

Among the 20 selected studies, nine were conducted in Asia, eight in Africa, and three in Latin America (see Table 1 for details of the studies, and Figure 1 for their location). The small number of studies is due to the lack of comparison between watersheds under forests and non-forest land uses and the lack of sufficient data in many studies. The focus of the meta-analyses on tropical areas, the theme of this special issue of Forest Ecology and Management, also strongly reduced the number of available studies, as tropical areas are under- 
represented in the scientific literature about forest hydrology. For example, among 135 watershed experiments reviewed in Andreassian (2004), only 16 are tropical watersheds.

$<<$ INSERT Table 1. Characteristics of the selected studies. $>>$

$<<$ INSERT Figure 1. Location of the 20 studies selected for the meta-analyses. $>>$

Among the 20 studies, 13 studies were conducted in watersheds smaller than $1 \mathrm{~km}^{2}$ and seven in watersheds larger than $1 \mathrm{~km}^{2}$. Seventeen studies compared watersheds with high forest cover difference (more than $50 \%$ of the watershed area). Seventeen studies were conducted in humid areas, and three in dry areas or transition areas between humid and dry. This result shows a bias in the meta-analyses, as no studies in semi-arid or arid areas and few studies in dry areas provided sufficient data. As the results cannot be generalized to the tropics as a whole, the scientific knowledge for decision making in dry, semi-arid, and arid areas is lacking.

In the 20 studies, we retrieved 63 comparisons between watersheds under natural or planted forests and nonforest land uses. On average, a comparison was based on 16 observations (e.g., one watershed observed during 16 years or four watersheds during four years). The numbers of studies and comparisons are within the acceptable range of sample sizes used in other meta-analyses. Indeed, in the few meta-analyses that have been applied to hydrology, the sample sizes were generally lower; for instance, 14 observations and four studies in Ilstedt et al. (2007).

\section{Natural forests}

In 12 of the 20 selected studies, 39 comparisons were analyzed between watersheds under natural forests and non-forest land uses. These comparisons were related mostly to watersheds larger than $1 \mathrm{~km}^{2}$ (26 comparisons), with high forest cover differences (24), and in humid areas (36). No studies about montane cloud forests complied with our selection criteria. As these forests can have a different effect on water flows compared to other natural forests because of their capacity to collect water from the clouds, valuation of ecosystem services or decision making about cloud forests should not be based on our meta-analyses.

Including all comparisons, the meta-analysis did not show significant differences in total flow between watersheds under natural forests and non-forest land uses (see Table 2). However, when selecting comparisons made in small watersheds or large differences in forest cover, the meta-analyses showed that the total flow was significantly lower in watersheds under natural forests than non-forest land uses. This result shows the interest in comparing small watersheds or watersheds with large differences in forest cover. Some authors have stated that the effects of forests on water flows are discernable only in watersheds smaller than $1000 \mathrm{~km}^{2}$ (FAO and CIFOR, 2005) or $500 \mathrm{~km}^{2}$ (Pattanayak, 2004), while others have stated that the most significant observations have been made in small watersheds, usually less than one $\mathrm{km}^{2}$ (Bruijnzeel, 2004). Separating the hydrological effects of forests is more difficult in larger catchments, which generally present diverse land uses and land-use changes.

$<<$ INSERT Table 2. Results of the meta-analyses. >>

The effect of natural forests on total flow has been demonstrated by other authors in diverse situations, although they may not be valid for some very old forests or cloud forests (Calder, 2002; Bruijnzeel et al., 2004). These effects can be explained by the higher evapotranspiration rates in forests compared to pasture or annual cropping land uses (Bruijnzeel, 1990). Trees with deep roots and high transpiration rates may act as pumps that remove water from the soil and transpire it. Although conversion of natural forests to nonforest land uses is immediately followed by a period of increased total flow, the subsequent period may not be characterized by a high total flow, for instance with forest recovery or high evapotranspiration rates in the subsequent vegetation. 
The meta-analysis showed no significant differences in base flow between watersheds under natural forests and non-forest land uses (see Table 2). The effect of natural forests on base flow results from two competing processes (Calder, 2002; Bruijnzeel et al., 2004): high transpiration by the forest, contributing to a low base flow, and high infiltration under the forest, generally contributing to soil water recharge and high base flow. If the infiltration capacity of the soil is increased when converting natural forests to non-forest land uses, base flow can be increased. Natural forests conserve base flow compared to other land uses in situations where the alternative land use decreases the infiltration capacity (Bruijnzeel et al., 2004). In the metaanalysis, the base flow was higher under natural forests for the subset of large watersheds; but this result is difficult to explain. This may due to the regional recycling of rainfall by forests (Vanclay, 2009) but this interpretation is controversial (Bruijnzeel, 2004).

Regarding storm flow, no significant difference was found between watersheds under natural forests and non-forest land uses (see Table 2). Forest hydrologists agree that the relationship between forests and storm flow is not clear (Bosch and Hewlett, 1982). Even if higher infiltration and evapotranspiration under forests may reduce storm flow, our results showed that this effect was not always significant. The role of forest cover for storm flow reduction is a debated issue, especially for the part of the storm flow that is released during extreme rainfall events (peak flow or maximum flow) and is responsible for floods. According to FAO and CIFOR (2005), there is no hard evidence that tropical forests reduce floods, while Bradshaw et al. (2007) showed that flood frequency is negatively correlated with forest cover. The effect of forests on large scale floods seems particularly weak; Bruijnzeel (2004) concluded that floods occurring in extreme conditions (e.g., extreme rainfall at the end of the rainy season when soils are wet) are not regulated by vegetation cover. Our analyses did not distinguish storm flows from rainfall events with different intensities, and thus it was not possible to determine the role of forests in regulating the peak flow resulting from extreme rainfall events. The regulation of annual storm flow is different from the regulation of peak flow resulting in large-scale floods (Bruijnzeel, 2004). However, even if forests do not prevent large scale floods, their role in preventing average and most frequent floods should not be undervalued.

\section{Planted forests}

In 10 of the 20 selected studies, 24 comparisons between watersheds under planted forests and non-forest land uses were analyzed. These comparisons were related mostly to watersheds smaller than $1 \mathrm{~km}^{2}(22$ comparisons), with high forest cover differences (all 24), and in humid areas (23). The selected studies referred to planted forests with species of two genera: Eucalyptus and Pinus. No studies were available for other species, including native species. This shows that there is a lack of scientific data for making decisions about planting species other than Eucalyptus and Pinus genera, as the results of the meta-analyses cannot be generalized to any planted forest in the tropics.

The meta-analyses showed that total flow and base flow were lower in watersheds under planted forests than non-forest land uses (see Table 2). These results can be explained by the high transpiration rates of exotic species, especially Eucalyptus (Vertessy et al., 2001). Infiltration capacity may be higher under planted forests than non-forest land uses (Ilstedt et al., 2007), but may not be enough to offset the higher loss of water by transpiration. However, some authors have reported that in degraded soils, planted forests may increase infiltration more than transpiration, thus increasing base flow, compared to non-forest land uses (Bruijnzeel, 2004). However, the available studies did not compare water flows between planted forests and non-forest land uses on degraded soils. Including all comparisons, the meta-analysis did not show significant differences in storm flow between watersheds with planted forests and non-forest land uses. This analysis of planted forests and storm flow was based on only five comparisons, compared to eight to 16 for other analyses.

\section{Usefulness of the meta-analyses}

The results of the meta-analyses allow the analysis of some misunderstandings about the effects of natural and planted forests on water flows in decision making on PES or watershed management. According to the 
conventional beliefs analyzed by various authors (Chomitz and Kumari, 1996; Susswein et al., 2001; Calder, 2002; Bruijnzeel et al., 2004; Kaimowitz, 2005), natural and planted forests are thought to increase total flows. This belief is deeply rooted in public perception, as was shown by Kosoy et al. (2007) in Central America, where more than $90 \%$ of the population involved in a survey perceived that more forests would lead to higher total water flows. According to FAO (2004), many hydrological PES are based on assumptions that have not been verified in the particular case. For example, in the PES scheme in Pimampiro (Ecuador), the effect of land-use of hydrological services has not been studied (Wunder and Albán, 2008). In Costa Rica, a private hydro-energy firm pays for ecosystem services provided by forestation and forest conservation with the objective of increasing its energy production, in part through increasing total flow (Miranda et al., 2007). Three PES schemes studied by Kosoy et al. (2007) in Central America are built upon the belief that forests increase total flows.

Aylward (2005) showed that several valuations of forest hydrological services were based on the unverified assumption that natural forests would decrease storm flow and increase base flow. Among the studies valuing forest watershed services in the FAO Forest Valuation Database (FAO, 2007), three were based on unsubstantiated relationships between forests and water, for instance that forests decrease floods or increase total flows. To supply water and reduce sediment in the Panama Canal, a plan developed in the 1990s promoted planting forests among other activities, and was based on the belief that planted forests would increase total and base flows (Calder, 2002; Kaimowitz, 2005). After hurricane Mitch in Central America in October 1998, the public, decision-makers, environmentalists, and international agencies were convinced that deforestation had increased the damage, and proposed forest planting as a watershed management measure (Kaimowitz, 2005). Similarly, Bruijnzeel (2004) reported that large-scale forest planting in upper watersheds was proposed in Bangladesh and China to reduce damage caused by floods.

Even though the results of the meta-analyses should not be generalized to any tropical watershed, total flows appeared to be lower in watersheds under natural forests than non-forest land uses (for small watersheds or with high differences in forest cover). The results show no significant differences in storm flow between watersheds under natural forests and non-forest land uses. Regarding planted forests, the results showed that they reduced base flow and total flow and had no significant effect on storm flow compared to non-forest land uses. These results highlight that the effects of natural or planted forests on water flows are not the same as perceived by some decision makers. Meta-analyses can help correct misunderstandings and show that some of the effects of natural or planted forests on water flows are unclear, and that inappropriate generalizations should be avoided (Tognetti et al., 2004).

\section{Limitations}

The meta-analyses faced several limitations. First, the small number of available studies limited the number of significant differences and prevented from taking into account other factors, for instance soil characteristics, geology, topography, rainfall pattern, location of land-use change in the watershed and land management in non-forest land areas, which are important factors in explaining the difference in water flows between forested and non-forested watersheds (Bruijnzeel, 2004; Aylward, 2005). Applying meta-analyses in a rigorous way is difficult with a small number of studies, especially with regards to the sensitivity analysis which is conducted on subsamples of the dataset. The following results were discarded by the sensitivity analysis: more base flow in watersheds under natural forests than under non-forest land uses (with all watersheds), less storm flow in watersheds under natural forests than under non-forest land uses (only with watersheds where forest cover differed by more than $50 \%$ of the watershed area), and less storm flow in watersheds under natural forests than under non-forest land uses (only with small watersheds).

Second, the available studies had been mostly conducted in humid areas and in some forest types (e.g., no cloud forests or planted forests with species other than of the Pinus and Eucalyptus genera). For these reasons, the results cannot be generalized to the entire tropics. Third, the available studies used different methods (e.g. for separating base flow and storm flow) and different time periods for calculating flow- 
rainfall ratios. A more thorough analysis of original hydrological data would be necessary to extend our simplified meta-analyses.

\section{Conclusions}

Meta-analysis appears to be a promising way to combine results from studies comparing water flows between tropical watersheds under natural or planted forests and non-forest land uses. It can help decision makers understand the effects of forests on water flows, and also highlight the effects that remain unclear. This help is necessary because even though hydrologists have published many narrative reviews about these effects, not all economists or decision makers have attempted to integrate this knowledge into the process of determining the value of hydrological ecosystem services or for making decisions. The meta-analyses show significantly lower total flows or base flows under planted forests than non-forest land uses. Meta-analyses conducted with subsamples of the data also show lower total flow and higher base flow under natural forests than non-forest land uses. However, the available studies were restricted to humid climates and particular forest types (Pinus and Eucalyptus planted forests and lowland natural forests).

The small number of available studies with sufficient data is a major constraint in the use of meta-analysis for analyzing the effects of natural or planted forests on water flows. It impedes analyzing the interacting effect of important factors for water flow regulation, such as soil, geology, topography, or land management practices. Furthermore, the available studies with sufficient data are restricted to some local conditions or forest types and knowledge is lacking about dry areas, cloud forests, native species plantations, and plantations on degraded lands.

The lack of measurements of water flow under different land-uses and of empirical data on hydrological services represents a major technical challenge for valuation studies or payment for ecosystem services (Kremen and Ostfeld, 2005), especially in countries where financial resources for implementing field research are scarce. More empirical data on underrepresented local conditions or forest types and a facilitated access to hydrological data would be valuable for watershed managers and decision-makers. Analyzing original data about water flows, climate and watershed characteristics in a consistent way could improve further application of meta-analysis.

\section{Acknowledgements}

The authors acknowledge Elke Verbeeten, Pablo Imbach, Carlos Perez, Daniel Murdiyarso, Thomas Koellner, Francisco Alpizar, and the anonymous reviewers for their useful comments. This document was produced within the framework of the project "Tropical Forests and Climate Change Adaptation" (TroFCCA), executed by CATIE and CIFOR and funded by the European Commission under contract EuropeAid/ENV/2004-81719. The contents of this document are the sole responsibility of the authors and can under no circumstances be regarded as reflecting the position of the European Union.

\section{References}

Andreassian, V., 2004. Water and forests: from an historical controversy to scientific debate. Journal of Hydrology, 291: 1-27.

Aylward, B., 2005. Land use, hydrological function and economic valuation. In: M. Bonell and L. A. Bruijnzeel (eds.), Forests, Water and People in the Humid Tropics: Past, present and future hydrological research for integrated land and water management. Cambridge University Press, pp.99-120.

Bailly, C., Benoit de Coignac, G., Malvos, C., Ningre, J.M. and Sarrailh, J.M., 1974. Etude de 1'influence du convert naturel et de ses modifications à Madagascar. Cahiers Scientifiques du Centre Technique Forestier Tropical No. 4, Nogent, France, 114 pp. 
Bergkamp, G., Orlando, B. Burton, I., 2003. Adaptation of Water Management to Climate Change. IUCN, Gland, Switzerland.

Best A, Zhang L, McMahon T, Western A, Vertessy R. 2003. A critical review of paired catchment studies with reference to seasonal flows and climate variability. Murray-Darling Basin Commission, Canberra, Au.

Bewket, W., Sterk, G., 2005. Dynamics in land cover and its effect on stream flow in the Chemoga watershed, Blue Nile basin, Ethiopia. Hydrological Processes, 19: 445-458.

Blackie, I. R., 1972. Hydrological effects of a change in land use from rain forest to tea plantation in Kenya. In: Proceedings of Symposium on the Results of Research on Representative and Experimental Basins, Wellington, NZ, IAHS Publication No. 97, pp. 312-329.

Bonell, M., Bruijnzeel, L.A.,. 2005. Forests, water and people in the humid tropics: past, present and future hydrological research for integrated land and water management. International Hydrology Series, Cambridge University Press.

Bonell, M., 1998. Possible effects of climate variability and change on tropical forest hydrology. Climatic change, 39: 215-272.

Bosch, J.M, Hewlett, J.D. 1982. A review of catchment experiments to determine the effect of vegetation changes on water yield and evapotranspiration. Journal of Hydrology, 55: 3-23.

Bradshaw, C.J.A., Sodhi, N.S., Peh, K.S.H., Brook, B.W., 2007. Global evidence that deforestation amplifies flood risk and severity in the developing world. Global Change Biology, 13: 1-17.

Bruijnzeel, L.A., 1990. Hydrology of moist tropical forests and effects of conversion: a state of knowledge review. UNESCO, Paris, 230 pp.

Bruijnzeel, L.A., 2004. Hydrological functions of tropical forests: not seeing the soil for the trees?. Agriculture, Ecosystems and the Environment, 104: 185-228.

Bruijnzeel, L.A.; Calder, I.R.; Vertessy, R.A., 2004. Forest hydrology: impacts of forest conversion on streamflow. In: J. Burley, J. Evans and J.A. Youngquist (eds.), The Encyclopedia of Forest Sciences. Oxford, Elsevier, pp.350-358.

Calder, I.R., 2002. Forests and hydrological services: reconciling public and science perceptions. Land Use and Water Resources Research, 2: 1-12.

Chandler, D. G., Walter, M. F., 1998. Runoff responses among common land uses in the uplands of Matalom, Leyte, Philippines. Transactions of the ASAE, 41(6): 1635-1641.

Chomitz, K., Kumari, K., 1996. The domestic benefits of tropical forests. Policy Research Working Paper 1601, World Bank, Washington, D.C.

Cooper, H., Hedges, L.V. (eds.), 1994. The Handbook of Research Synthesis. Russell Sage Foundation, New York, 573 pp.

Costa, M. H., Botta, A., Cardille, J., 2003. Effects of large-scale changes in land cover on the discharge of the Tocantins River, Southeastern Amazonia. Journal of Hydrology, 283(1): 206-217.

Critchley, W.R.S., Bruijnzeel, L.A., 1996. Hydrological impacts of conversion of moist tropical forests to agriculture and plantations. IHP Humid Tropics Programme series nº10, UNESCO, Paris, 50 pp.

Dagg, M., Blackie, J.R., 1965. Studies of the effects of changes in land use on the hydrological cycle in East Africa by means of experimental catchment areas. Bulletin of the International Association of Scientific Hydrology, 10 (4): 63-75.

Deichmann U., Eklundh L., 1991. Global digital data sets for land degradation studies: a GIS approach. GRID Case Study Series No. 4; UNEP/GEMS and GRID; Nairobi, Kenya; 103 p. (data available at: http://www-cger.nies.go.jp/grid-e/gridtxt/hind_geo.html). 
Dudley N., Stolton S., 2003. Running pure: the importance of forest protected areas for drinking water. World Bank, Washington D.C., 114p.

FAO, 2004. Payment schemes for environmental services in watersheds: regional forum, 9-12 June 2003, Arequipa, Peru. Land and Water Discussion Paper nº3, FAO, Roma, 88 pp.

FAO, 2007. Forest valuation database. Developed under the EC-FAO Partnership Programme on Data Collection and Analysis. FAO, Roma accessed on 19 April 2007 www.fao.org/forestry/valuation

FAO, CIFOR, 2005. Forests and floods: Drowning in fiction or thriving on facts? Forest Perspectives Series n², CIFOR, Bogor, Indonesia, 40 pp.

Farley, KA, Jobbagy, EG, Jackson, RB., 2005. Effects of afforestation on water yield: a global synthesis with implications for policy. Global Change Biology, 11: 1565-1576.

Fernandez-Duque, E., Valeggia, C., 1994. Meta-analysis: a valuable tool in conservation research. Conservation Biology, 8(2): 555-561.

Fritsch, J.M., 1983. Modifications des écoulements après défrichement et aménagements agro-forestiers de bassins versants expérimentaux en Guyane française. In: Le Projet ECEREX (Guyane) : analyse de l'écosystème forestier tropical humide et des modifications apportées par l'homme. Journées de Cayenne, Cayenne (GF), ORSTOM, Paris, p.260-304.

Fritsch, J.M., 1992. Les effets du défrichement de la forêt amazonienne et de la mise en culture sur l'hydrologie des petits vassins versants. ORSTOM éditions, Paris, 392 pp.

Fujieda, M.; Kudoh, T.; deCicco, V.; Calvarcho, J.L. 1997. Hydrological processes at two subtropical forest catchments: the Serra do Mar, Sao Paulo, Brazil. Journal of Hydrology, 196: 26-46.

Goujon, P., Bailly, C., de Vergnette, J., Roche, P., 1968. Essai de mise en valeur agricole par aménagement rationnel des bassins versants : le périmètre de Manankazo sur les hauts plateaux malgaches. Bois et Forêts des Tropiques, 121: 19-34.

Guillemette, F, Plamondon, AP, Prevost, M, Levesque, D., 2005. Rainfall generated stormflow response to clearcutting a boreal forest : peakflow comparison with 50 world-wide basin studies. Journal of Hydrology, 302: 137-153.

Guo, Z., Xiao, X., Li, D., 2000. An assessment of ecosystem services: water flow regulation and hydroelectric power production. Ecological Applications, 10 (3): 925-936.

Gurevitch, J., Curtis, P.S., Jones, M.H., 2001. Meta-analysis in Ecology. Advances in Ecological Research, 32: 199-247.

Hulme P. 2005. Adapting to climate change: is there scope for ecological management in the face of a global threat? Journal of Applied Ecology, 42: 784-794.

Ilstedt, U., Malmer, A., Verbeeten, E., Murdiyarso, D., 2007. The effect of afforestation on water infiltration in the tropics: A systematic review and meta-analysis. Forest Ecology and Management, 251(1-2): 45-51.

Kaimowitz, D., 2005. Useful Myths and Intractable Truths: the Politics of the Link Between Forests and Water in Central America. In: M. Bonell and L. A. Bruijnzeel (eds.), Forests, Water and People in the Humid Tropics: Past, present and future hydrological research for integrated land and water management.

Cambridge University Press, pp.86-98.

Kosoy, N., Martinez-Tuna, M., Muradian, R., Martinez-Alier, J., 2007. Payments for environmental services in watersheds: Insights from a comparative study of three cases in Central America. Ecological Economics, 61(2-3), 446-455.

Kremen, C., Ostfeld, R.S., 2005. A call to ecologists: measuring, analyzing, and managing ecosystem services. Front Ecol Environ, 3(10): 540-548. 
Lal, R., 1997. Deforestation effects on soil degradation and rehabilitation in western Nigeria. IV. Hydrology and water quality. Land Degradation and Development, 8(2): 95-126.

Mathur, H.N., Babu, R., Joshie, P. and Singh, B., 1976. Effect of Clearfelling and Reforestation on Runoff and Peak Rates in Small Watersheds. Indian Forester, 102(4):219-26

Millennium Ecosystem Assessment, 2005. Ecosystems and Human Well-being: Synthesis. Island Press, Washington, DC., 137pp.

Miranda, M., Dieperink, C., Glasbergen, P., 2007. Voluntary agreements in watershed protection experiences from Costa Rica. Environment, Development and Sustainability, 9(1): 1-19.

Mungai, D.N., Ong, C.K., Kiteme, B., Elkaduwa, W., Sakthivadivel, R., 2004. Lessons from two long-term hydrological studies in Kenya and Sri Lanka. Agriculture, Ecosystems and Environment, 104(1): 135-143.

Mwendera, E. J., 1994. Effect on the water yield of the Luchelemu catchment in Malawi of replacing indigenous grasses with timber plantations. Forest Ecology and Management, 65(2-3): 75-80.

Oki, T., Kanae, S., 2006. Global hydrological cycles and world water resources. Science, 313: 1068-1072.

Pagiola, S., 2008. Payments for environmental services in Costa Rica. Ecological Economics 65, 713-725.

Pattanayak, SK., 2004. Valuing watershed services: concepts and empirics from Southeast Asia. Agriculture, Ecosystems and Environment, 104: 171-184.

Raghunath, B., Das, D. C., Thomas., P. K., 1970. Some results of investigations on hydrology of the subwatersheds in the Nilgiris (India). In: Proceedings of Symposium on the Results of Research on Representative and Experimental Basins, Wellington, NZ., IAHS Publication nº96, pp. 416-440.

Sahin, V., Hall, M.J., 1996. The effects of afforestation and deforestation on water yields. Journal of hydrology, 178: 293-309.

Samraj, P., Sharda, V.N., Chinnamani, S., Lakshmanan, V., Haldorai, B., 1988. Hydrological behaviour of the Nilgiri sub-watersheds as affected by bluegum plantations, Part I. The annual water balance. Journal of Hydrology, 103(3-4): 335-345.

Scott, D.F., Bruijnzeel, L.A., Mackensen, J., 2005. The hydrological and soil impacts of forestation in the tropics. In: M. Bonell and L. A. Bruijnzeel (eds.), Forests, Water and People in the Humid Tropics: Past, present and future hydrological research for integrated land and water management. Cambridge University Press, pp. 622-651.

Scott, D.F.; Bruijnzeel, L.A.; Vertessy, R.A.; Calder, I.R. 2004. Forest hydrology: impacts of forest plantations on streamflow. In: J. Burley, J. Evans and J.A. Youngquist (eds.), The Encyclopedia of Forest Sciences. Oxford, Elsevier, pp.367-377.

Shadish, W.R., Haddock, C.K., 1994. Combining estimates of effect size. In: H. Cooper, L.V. Hedges (eds.). The Handbook of Research Synthesis. Russell Sage Foundation, New York, pp.261-281.

Sharda, V. N., Samraj, P., Samra, J.S., Lakshmanan, V., 1988. Hydrological behaviour of the Nilgiri subwatersheds as affected by blue gum plantations, Part II. Monthly water balances at different rainfall and runoff probabilities. Journal of Hydrology, 103(3-4): 347-355.

Sikka, A. K., Samra, J. S., 2003. Low flow and high flow responses to converting natural grassland into bluegum (Eucalyptus globulus) in Nilgiris watersheds of South India. Journal of Hydrology, 270(1-2): 12-26.

Smakhtin V.U., 2001. Low flow hydrology: a review. Journal of Hydrology 240: 147-186.

Susswein, P.M., van Noordwijk, M., Verbist, B.., 2001. Forest watershed functions and tropical land use change. Towards integrated natural resource management in forest margins of the humid tropics: local action and global concerns. ASB Lecture Note 7. International Centre for Research for Agroforestry, Bogor, Indonesia, 38pp. 
Tognetti, S.S., Mendoza, G, Aylward, B., Southgate, D., Garcia, L., 2004. A knowledge and assessment guide to support the development of payment arrangements for watershed ecosystem services. Working Paper. Environment Department, World Bank, Washington, DC.

UNESCO, WMO, 1992. International glossary of hydrology. Paris, United Nations Educational Scientific and Cultural Organization ; Geneva, World Meteorological Organization, 1992.

van Noordwijk, M., Poulsen, J.G., Ericksen, P.J.., 2004. Quantifying off-site effects of land-use change: filters, flows and fallacies. Agriculture, Ecosystems and Environment, 104: 19-34.

Vanclay, J.K., 2009. Managing water use from forest plantations. Forest Ecology and Management 257: 385-389.

Vertessy, R.A., Watson, F.G.R., O'Sullivan, S.K., 2001. Factors determining relations between stand age and catchment water balance in mountain ash forests. Forest Ecology and Management, 143: 13-26.

Waage, S., Bracer, C., Inbar, M., 2008. Payments for Ecosystem Services: Getting started. Forest Trends, the Katoomba Group, UNEP, Washington DC.

Wilk, J., Andersson, L., Plermkamon, V., 2001. Hydrological impacts of forest conversion to agriculture in a large river basin in northeast Thailand. Hydrological Processes, 15(14): 2729-2748.

Wunder, S., 2005. Payments for environmental services: some nuts and bolts. Occasional Paper 42, CIFOR, Bogor, Indonesia, $32 \mathrm{pp}$.

Wunder, S., Albán, M., 2008. Decentralized payments for environmental services: The cases of Pimampiro and PROFAFOR in Ecuador. Ecological Economics, 65: 685-698.

Wunder, S., Engel S., Pagiola S., 2008. Taking stock: A comparative analysis of payments for environmental services programs in developed and developing countries. Ecological Economics 65: 834-852.

Zhou, G.Y., Morris, J.D., Yan, J.H., Yu, Z.Y., Peng, S.L., 2002. Hydrological impacts of reafforestation with eucalypts and indigenous species: a case study in southern China. Forest Ecology and Management, 167(1): 209-222.

\section{Tables and Figure}


Table 1. Characteristics of the selected studies.

\begin{tabular}{|c|c|c|c|c|c|c|}
\hline $\begin{array}{l}\text { First } \\
\text { author and } \\
\text { year }\end{array}$ & Country & $\begin{array}{l}\text { Humidity } \\
\text { class (2) }\end{array}$ & $\begin{array}{l}\text { Watershed } \\
\text { area (3) }\end{array}$ & $\begin{array}{l}\text { Forest } \\
\text { cover } \\
\text { difference } \\
\text { (4) }\end{array}$ & Years (5) & Description (6) \\
\hline $\begin{array}{l}\text { Bailly } \\
1974 p(1)\end{array}$ & $\begin{array}{l}\text { Mada- } \\
\text { gascar }\end{array}$ & $\mathrm{HU}$ & $\mathrm{S}$ & $\mathrm{Hi}$ & $64-71$ & $\begin{array}{l}\text { NF Syn (4 w. forest, } 2 \text { w. agriculture/fallow) } \\
\text { PF Syn (1 w. Eucalyptus, } 2 \text { w. agriculture/fallow) }\end{array}$ \\
\hline $\begin{array}{l}\text { Bailly } \\
1974 \mathrm{~m}\end{array}$ & $\begin{array}{l}\text { Mada- } \\
\text { gascar }\end{array}$ & $\mathrm{HU}$ & $\mathrm{S}$ & $\mathrm{Hi}$ & $62-72$ & PF Syn (1 w. Eucalyptus, 2 w. grassland) \\
\hline $\begin{array}{l}\text { Bewket } \\
2005\end{array}$ & Ethiopia & $\mathrm{HU}$ & $\mathrm{L}$ & Lo & $\begin{array}{l}60-64 \text { and } \\
80-84\end{array}$ & NF Dia (1 w. less forested in 1960 than in 1982). \\
\hline $\begin{array}{l}\text { Blackie } \\
1972\end{array}$ & Kenya & HU-DR & $\mathrm{L}$ & $\mathrm{Hi}$ & $61-68$ & NF Syn (1 w. forest, 1 w. partially agriculture) \\
\hline $\begin{array}{l}\text { Chandler } \\
1998\end{array}$ & $\begin{array}{l}\text { The } \\
\text { Phili- } \\
\text { ppines }\end{array}$ & $\mathrm{HU}$ & $\mathrm{S}$ & $\mathrm{Hi}$ & $95-96$ & NF Syn (1 w. forest, 2 w. grasslands) \\
\hline $\begin{array}{l}\text { Costa } \\
2003\end{array}$ & Brazil & $\mathrm{HU}$ & $\mathrm{L}$ & Lo & $\begin{array}{l}49-68 \text { and } \\
79-98\end{array}$ & NF Dia (1 w. less forested in 49-68 than in 79-98). \\
\hline $\begin{array}{l}\text { Dagg } \\
1965\end{array}$ & Tanzania & $\mathrm{HU}$ & $\mathrm{S}$ & $\mathrm{Hi}$ & $57-63$ & NF Syn (1 w. forest, 1 w. agriculture) \\
\hline $\begin{array}{l}\text { Fritsch } \\
1983\end{array}$ & $\begin{array}{l}\text { French } \\
\text { Guyana }\end{array}$ & $\mathrm{HU}$ & $\mathrm{S}$ & $\mathrm{Hi}$ & $77-81$ & NF Syn (2 w. forest, 6 w. deforested/pasture) \\
\hline $\begin{array}{l}\text { Fritsch } \\
1992\end{array}$ & $\begin{array}{l}\text { French } \\
\text { Guyana }\end{array}$ & $\mathrm{HU}$ & $\mathrm{S}$ & $\mathrm{Hi}$ & $77-87$ & $\begin{array}{l}\text { NF Syn ( } 2 \text { w. forest, } 2 \text { w. pasture/slash-and-burn) } \\
\text { PF Dia ( } 2 \text { w. before and after reforestation) }\end{array}$ \\
\hline $\begin{array}{l}\text { Goujon } \\
1968\end{array}$ & $\begin{array}{l}\text { Mada- } \\
\text { gascar }\end{array}$ & $\mathrm{HU}$ & $\mathrm{S}$ & $\mathrm{Hi}$ & $62-66$ & PF Syn (1 w. Pinus, 1 w. grassland) \\
\hline Lal 1997 & Nigeria & HU-DR & $\mathrm{S}$ & $\mathrm{Hi}$ & $\begin{array}{l}74-75 \text { and } \\
79-84\end{array}$ & NF Dia (1 w. deforested in 1979) \\
\hline $\begin{array}{l}\text { Mathur } \\
1976\end{array}$ & India & DR & $\mathrm{S}$ & $\mathrm{Hi}$ & $\begin{array}{l}61-67 \text { and } \\
69-73\end{array}$ & $\begin{array}{l}\text { PF Syn (after } 19691 \text { w. Eucalyptus, } 1 \text { w. shrub) } \\
\text { PF Dia (1 w. under shrub before 1968, then } \\
\text { Eucalyptus) }\end{array}$ \\
\hline $\begin{array}{l}\text { Mungai } \\
2004\end{array}$ & $\begin{array}{l}\text { Sri } \\
\text { Lanka }\end{array}$ & HU & $\mathrm{L}$ & Lo & $\begin{array}{l}51-61,67- \\
77,78-88\end{array}$ & NF Dia (1 w. under deforestation) \\
\hline $\begin{array}{l}\text { Mwendera } \\
1994\end{array}$ & Malawi & $\mathrm{HU}$ & $\mathrm{L}$ & $\mathrm{Hi}$ & $\begin{array}{l}61-65,70- \\
78\end{array}$ & $\begin{array}{l}\text { PF Dia (1 w. under forestation with Pinus and } \\
\text { Eucalyptus) }\end{array}$ \\
\hline $\begin{array}{l}\text { Raghunath } \\
1970\end{array}$ & India & $\mathrm{HU}$ & $\mathrm{L}$ & $\mathrm{Hi}$ & $\begin{array}{l}\text { Various } \\
\text { periods }\end{array}$ & $\begin{array}{l}\text { NF Syn ( } 9 \text { w. mainly under agriculture or pasture, } 3 \\
\text { w. mainly under forest) }\end{array}$ \\
\hline $\begin{array}{l}\text { Samraj } \\
\text { 1988; } \\
\text { Sharda } \\
\text { 1998; } \\
\text { Sikka } \\
2003\end{array}$ & India & $\mathrm{HU}$ & $\mathrm{S}$ & $\mathrm{Hi}$ & $\begin{array}{l}68-71,73- \\
81,82-91\end{array}$ & $\begin{array}{l}\text { PF Syn (after } 19721 \text { w. Eucalyptus, } 1 \text { w. shrub) } \\
\text { PF Dia (1 w. under shrub before 1972, then } \\
\text { Eucalyptus) }\end{array}$ \\
\hline Wilk 2001 & Thailand & $\mathrm{HU}$ & $\mathrm{L}$ & $\mathrm{Hi}$ & $\begin{array}{l}57-64,87- \\
94\end{array}$ & NF Dia (1 w. with decreasing forest cover) \\
\hline $\begin{array}{l}\text { Zhou } \\
2002\end{array}$ & China & $\mathrm{HU}$ & (2) & $\mathrm{Hi}$ & $81-90$ & PF Syn (1 w. Eucalyptus, 1 w. bare soil) \\
\hline \multicolumn{7}{|c|}{$\begin{array}{l}\text { (1) Two studies are reported in the same reference (Bailly et al., 1974), one in Périnet (1974p) and another in Manankazo (1974m). } \\
\text { (2) HU=humid area, HU-DR= humid area near the transition between humid and dry (less than 50km), DR=dry area. Humidity index taken from } \\
\text { Deichmann and Eklundh }(1991) \text {. } \\
\text { (3) S=Small }\left(<1 \mathrm{~km}^{2}\right), \mathrm{L}=\text { Large }\left(>1 \mathrm{~km}^{2}\right) \text {. } \\
\text { (4) Lo: forest cover differs by less than } 50 \% \text { of the watershed area between the compared watersheds, Hi: more than } 50 \% \text {. } \\
\text { (5) Period(s) of time selected for our analysis. } \\
\text { (6) NF: comparisons between natural forests and non-forest land uses, PF: comparison between planted forests and non-forest land uses. Syn: } \\
\text { synchronic comparisons. Dia: diachronic comparisons. In parenthesis: description of watershed land cover ("w." = watershed). }\end{array}$} \\
\hline
\end{tabular}


Table 2. Results of the meta-analyses.

\begin{tabular}{|l|l|l|l|}
\hline $\begin{array}{l}\text { Results of the meta- } \\
\text { analysis with all data }\end{array}$ & Selected studies (i) & $\begin{array}{l}\text { Number of comparisons } \\
\text { and characteristics of the } \\
\text { compared watersheds (ii) }\end{array}$ & $\begin{array}{l}\text { Other significant results of the } \\
\text { meta-analyses with data subsets } \\
\text { (ii) }\end{array}$ \\
\hline \multicolumn{3}{|c|}{$\begin{array}{l}\text { Differences in flows between natural forests vs. non-forest land uses } \\
\text { (Studies available only for lowland forests. No studies on cloud forests). }\end{array}$} \\
\hline $\begin{array}{l}\text { Total flow: No significant } \\
\text { difference }\end{array}$ & $\begin{array}{l}\text { 11 (Bai74p Bew05 Bla72 } \\
\text { Cha98 Cos03 Dag65 Fri83 } \\
\text { Lal97 Mun04 Rag70 Wil01) }\end{array}$ & $\begin{array}{l}15 \text { (6 small w, 9 large } \\
\text { w, 3 dry, 12 humid, 11 } \\
\text { high diff., 4 low diff) }\end{array}$ & $\begin{array}{l}\text { With small w. or high diff.: Less } \\
\text { total flow in natural forest than } \\
\text { non-forest land uses }\end{array}$ \\
\hline $\begin{array}{l}\text { Base flow: No significant } \\
\text { difference }\end{array}$ & $\begin{array}{l}\text { 4 (Bai74p Bew05 Mun04 } \\
\text { Wil01) }\end{array}$ & $\begin{array}{l}8 \text { (1 small w, 7 large w, } \\
8 \text { humid, 2 high diff., 6 } \\
\text { low diff.) }\end{array}$ & $\begin{array}{l}\text { In large w.: More base flow in } \\
\text { natural forest than non-forest land } \\
\text { uses }\end{array}$ \\
\hline $\begin{array}{l}\text { Storm flow: No significant } \\
\text { difference }\end{array}$ & $\begin{array}{l}8 \text { (Bai74p Bew05 Cha98 } \\
\text { Cos03 Fri92 Mun04 Rag70 } \\
\text { Wil01) }\end{array}$ & $\begin{array}{l}16 \text { (6 small w, 10 large } \\
\text { w, 16 humid, 9 high } \\
\text { diff., 7 low diff.) }\end{array}$ & None \\
\hline \multicolumn{1}{|c|}{ Diftudies available only about Eucalyptus and Pinus plantations. No studies on other species, incl. native species). } \\
\hline $\begin{array}{l}\text { Total flow: Less total flow } \\
\text { in planted forest than non- } \\
\text { forest land uses }\end{array}$ & $\begin{array}{l}7 \text { (Bai74m Bai74p Gou68 } \\
\text { Mat76 Sam88 Sha98 Zho02) }\end{array}$ & $\begin{array}{l}11 \text { (11 small w, 1 dry, } \\
10 \text { humid, 11 high } \\
\text { diff.) }\end{array}$ & $\begin{array}{l}\text { With small w., humid or high diff.: } \\
\text { Same result }\end{array}$ \\
\hline $\begin{array}{l}\text { Base flow: Less base flow } \\
\text { in planted forest than non- } \\
\text { forest land uses }\end{array}$ & $\begin{array}{l}5 \text { (Bai74p Mwe94 Sam88 } \\
\text { Sha98 Sik03) }\end{array}$ & $\begin{array}{l}\text { 8 (7 small w, 1 large w, } \\
8 \text { humid, 8 high forest } \\
\text { diff.) }\end{array}$ & $\begin{array}{l}\text { With small w., humid or high diff.: } \\
\text { Same result }\end{array}$ \\
\hline $\begin{array}{l}\text { Storm flow: No significant } \\
\text { difference }\end{array}$ & $\begin{array}{l}5 \text { (Bai74p Gou68 Mwe94 } \\
\text { Sam88 Sha9) }\end{array}$ & $\begin{array}{l}5 \text { (4 small w, 1 large w, } \\
5 \text { humid, 5 high diff.) }\end{array}$ & None \\
\hline
\end{tabular}

(i) Number of studies and references in parenthesis (references are given with the first three letters of the first author's name and the 2-digit year).

(ii) "small w." = watershed smaller than $1 \mathrm{~km}^{2}$, "large w." = watershed larger than $1 \mathrm{~km}^{2}$, "humid" = humid according to Table 1 definition, "dry" = dry or transition from humid to dry, "low diff." = forest cover differs by less than $50 \%$ of the watershed area between the compared watersheds, "high diff."= more than 50\%. 
Figure 1. Location of the 20 studies selected for the meta-analyses.

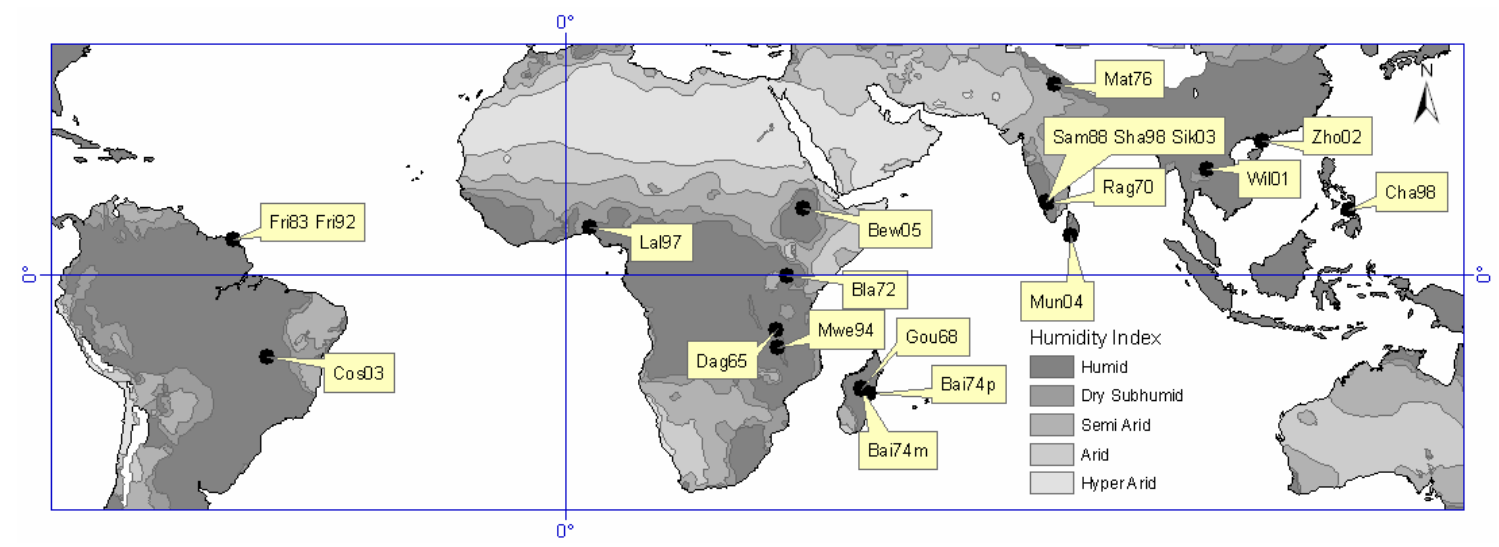

